\section{An Evaluation Related to the Effect of Strategic Facility Management on Choice of Medical Tourism Destination}

\author{
Ertugrul Tarcan, Metin Ates, Ergin Sait Varol
}

\section{INTRODUCTION}

Medical Tourism, which ranges from the health care services involving a cure to the wellness services involving no specific health trouble to pleasure and amusement services, is one of the most growing sectors in almost all of the developed and developing countries (Connell, 2011).

Individuals have three worlds that can be named as the world of physical, emotional and mental. Physical world has a positive relationship with the mental and emotional conditions of the people. While evaluating the services taken, people are largely under the influence of the physical environment (WHO Regional, 1998; Tarcan, 2001; Roper \& Borello, 2014). A medical tourist doesn't have enough technical information about his or her demand of medical destination. So the decision of this medical tourist on the choice of destination and the quality of services provided is greatly influenced by his or her feelings about the medical facility/facilities (physical environment). Additionally, the outcome quality of the medical services is also related to the adequacy of medical facilities. Even though it did not receive the attention it deserves, facility management (FM) may be an invaluable tool to be used for creating value in tourism businesses (Tarcan, 1998; Tarcan, 2001; Connell 2011).

Cost and quality of medical services are among the main reasons for the choice of medical tourism destination. Managers of medical tourism, whereas focus on core services of medical and wellness, generally neglect opportunities in the field of FM that they can use to enhance efficiency, effectiveness and efficacy (Bernard \& Payant, 2007, p. 1.11-1.12; Tarcan, 1998). Facility management as a sufficiently untouched field can be seen as an area to be evaluated by managers in achieving lower costs of medical tourism businesses without compromising quality.

\section{HEALTH TOURISM}

Medical Tourism, being one of the most growing sectors in almost all of the developed and developing countries, can be classified in the field of niche tourism. It ranges from the health care services involving a cure, such as organ transplant, cardiac surgery, eye surgery, hip replacement, cosmetic dentistry and fertility treatments, to the wellness services such as spa and detox involving no specific health trouble, but pleasure
Abstract: This study based on literature review aims to evaluate and emphasize the affect of the strategic facility management (SFM) on choice of medical tourism destination. Medical Tourism, which ranges from the health care services involving a cure to the wellness services involving no specific health trouble to pleasure and amusement services, is one of the most growing sectors in the world. Cost and quality of medical services are among the main reasons for the choice of destination. Strategic facility management has a positive correlation on the levels of quality, cost and customer satisfaction. Thus medical tourism and destination managers should take into account of the potential advantages of value creation offered through SFM in order to be chosen by customers (stakeholders).

Keywords: strategic facility management, medical tourism, choice of destination. 
and amusement services. On the other hand, Connell (2011) indicates that medical tourism is concentrated in the more physical health field such as biophysical processes; he explains the tourism of wellness services such as diet, exercise and thought trends as health tourism. But physical, social and mental well-beings are inseparable. Therefore the medical and health tourism terms are preferred for use together in this study in spite of different classifications in literature (Sultana et al., 2014).

Medical tourism might be one of the ways of solution for the lack of source on funding the health care expenditures. Health care systems need huge amount of source projected to increase even more in the future for reasons such as rising life expectancy, obesity, new types of illnesses, etc. The proportion of total health expenditure of the countries to gross domestic product ranges from $2 \%$ to $17.1 \%$ of their gross national product (The Word Bank, 2013, p.1); for example, this proportion in United States is estimated to raise from $17.1 \%$ to $19.3 \%$ in 2019 , and more than $20 \%$ with the effect of the Affordable Care Act (ACA) or Obama Care in the 2020s (Ginter, Duncan \& Swayne, 2013, pp.1-4).

Medical tourism has also a role in creating value for stakeholders as shareholders, internal customers, healthcare insurance systems, all of the sectors etc. Most of the medical tourism products, in order to be marketed, need compatibility with standards and/or accreditations. So the medical tourism contributes to achieving these higher levels of quality.

In the field of medical tourism, the reliable infrastructure is needed in order to deliver the core and non-core services such as in the hospitals, medical imaging centers, shopping and amusement centers, transportation, etc. Infrastructures and environmental factors such as climate, flora and fauna may be an advantage for the choice of destination as comparative factors. On the other hand, the factors related to the medical services indicate the competitive features.

The major reasons for the demand of medical services outside region or country can be specified as high medical prices, lack of medical insurance, under insurance, longer waiting time, lower quality in residence area, demand for cosmetic surgery, confidentiality, combining medical care with a holiday and so on (Connell, 2011; Sultana et al., 2014, Han \& Hyun 2015).

Stakeholders of the medical tourism can be stated in a wide range from patients (medical tourists), employees and suppliers to insurance systems, legislative organs and travel agencies.

\section{CRITERIA OF DESTINATION CHOICE IN THE HEALTH TOURISM}

The most satisfying factors for customers of medical tourism are the cost and quality of this travel, which are among the main reasons for the choice of destination. It can be said that the lower cost and higher quality means the higher demand for medical touri$\mathrm{sm}$. The steadily increasing volume of medical tourism requires that managers in this field uncover some new ways of reducing costs and implement them while improving quality, without compromising on quality (Bernard \& Payant, 2007; Gallagher, 1998; Tarcan, 1998; Roper 2014).

\subsection{Customer/Shareholder Satisfaction}

Satisfied customer is a crucial aspect of the sustainability of medical tourism businesses based on service. Medical service providers have been engaged in processes of core and non-core activities while delivering services in order to satisfy healthcare customers (stakeholders) with higher quality and lower price than their competitors (Han \& Hyun, 2015; Tarcan, 2001).

Employees' behaviors in service-intense sectors, while delivering services, play an important role on the contribution to the satisfaction levels of customers. Performance levels of an organization in especially service-intensive sectors relate with the satisfaction levels of workers and also quality levels of outcomes are related to the workers' satisfaction. On the other hand employee satisfaction is also an invaluable tool in the terms of human source for sustainable employment in an environment of business world being an acute lack of qualified medical workforce currently and in the future (Beladi, Chao, Ee \& Hollas, 2015; Packer, Labonté \& Spitzer, 2007; Tarcan, 2001). Environmental conditions such as lighting, indoor air quality, ergonomics and acoustics have a great effect on satisfaction of stakeholders; consequently on companies' performances (Tarcan, Varol \& Ates, 2004).

\subsection{Cost}

Cost is an important competing factor in decision of destination of medical tourism (Han \& Hyun, 2015). Unfortunately it can be said that there isn't enough available data in the world for comparing the costs of facility management, and this field is open to research for reducing costs and improving quality. Even in the designing stage of facilities, it is not obvious how the costs of FM will be considered the cost of services. Although there isn't enough reference information 
in the literature, facilities, which are tangible assets/ environment that supports the core activities, costs 20-30\% of expenditures of hospitals (Rechel, Wright \& Edwards, 2009, p. 167). Medical service providers have been engaged in processes of core and non-core activities while delivering services in order to satisfy healthcare customers (stakeholders) with higher quality and lower price than their competitors. Asian Countries have advantage of price when comparing with the Western countries. Lesser prices in Asia attract more medical tourists than United States and European countries. Because of that medical tourists can save from $40 \%$ up to $\% 60$ in Thailand, India, Malaysia and Singapore as destination of medical tourism which are in front lines in the world; among these countries, India stands out in terms of competition (Kshetri, 2011, p. 454; Connell, 2011).

\subsection{Quality}

Given the opportunities of facility management, medical tourism businesses can have new advantages in competition via lower costs and higher service quality and customer satisfaction (Han \& Hyun, 2015; Shiem \& Then, 1999, p. 466; Tarcan, 2001).

Necessity of having accreditation and quality standards forces and helps medical businesses to improve beyond the current quality level of their products in an environment of international or/and global trade. The achievement of accreditation and quality standards assures that organizations can supply enough quality in delivering their products. Accreditation and/or quality systems also assure businesses to follow the developments in the medical tourism area, because they have to sustain their compliance with the conditions of accreditation and quality systems of their tangible or intangible products. Accreditation improves employees' satisfaction, public trust, strengthened leadership, stakeholder satisfaction and so on. It also displays that goods and services are being recognized as complying with the standards of global desired. Certificates of accreditation and quality systems make the self-assessment procedure done by customers much easier (Emslie, Knox \& Pickstone, 2003; Nicklin, 2012, Tarcan, 2001; The Joint Commission, 2015, pp. 59-64).

\section{FACILITIES}

Facilities are the physical assets such as general building, social areas, clinical buildings and equipment of fire, electrical, security, plumbing, information technology and the other things. Most of facilities in medical tourism are operational longer hours than the normal working hours or 24 hours a day, 7 days a week. On the other hand, indoor facilities exhibit a privileged importance throughout the human life in addition to the production of goods and services. It is explained that an ordinary employee spends more time than 23 hours per day in indoor environments (Mahbob et al. 2011, p. V2-434).

Facilities should be seen as one of the major fields to be considered to enhance the competitiveness of organizations and thus stakeholders' satisfaction levels. Facilities may be an alternative source field that manager can use to be able to create value for customers (stakeholders). A growing number of facility managers and related groups such as owners, architects and designers, etc. have started to be much more interested in the features of facilities, in order to create value.

In the decision process of destination choice, the overall adequacy of the facilities in the region can play an invaluable role. Facilities are among the most affecting factors in assessment of the service-based medical products such as medical examination, cardiac surgery etc. Facilities are also related to the nosocomial infections, medical malpractices, length of hospital stay, rate of diseases caught while staying in medical environments, medical malpractice rate and so on. (Hofer \& Stampfli, 2012, p. 1; Tarcan, 1998; Tarcan, 2001).

The recent research indicates that the higher comfort level of facility results in the less health problems and the higher general sufficiency of facility. And the higher general sufficiency of facility has positive effects on the performance of business Tarcan, 2005; Tarcan, 2008).

Facilities have been generally perceived as a cost center until now. The new trend is to think of them as a potential value center. The new viewpoint is that expenditures to be made to the facilities can be returned as value to all customers. At the end, a better facility will be able to produce higher stakeholder satisfaction (Roper, 2014).

\subsection{Facility Management}

Facilities being tangible assets have direct and indirect effects on the outputs of production if they are properly managed by facility managers (Tarcan, 1998; Roper 2014). International Facility Management Organization (International, 2015, p. 1) defines the FM 
as "A profession that encompasses multiple disciplines to ensure functionality of the built environment by integrating people, place, process and technology." Facility management includes the duties of providing a reliable environment for stakeholders in order to deliver goods or/and services in the healthy, efficiently and effectively conditions. The viewpoint of facility management should be in the direction of creating a reliable environment encouraging higher outcomes of wellness, healing and satisfaction. The task area of facility manager includes jobs ranging from designing, maintenance to security (Sultana et al., 2014).

Most of buildings, even the newer ones, create inconvenience conditions negatively affecting the outputs of core services. Sick building syndrome is unknown enough by managers as one of significant problems of facility management. Sick buildings can be described as buildings showing signs of uncomforting and health symptoms such as asthma, allergic problems, cancer, legionnaire disease, Pontiac fever (Enderwick \& Nagar, 2011; Tarcan, 1998). There is a positive relation between service quality and adequacy of facilities. Levels of adequacy of facilities also highly effect the rates of medical malpractice. So, medical tourism businesses may be forced more to pay compensation for their inadequate services due to the legal requirements being expanded. When facilities of medical are managed as needed, time spent for medical service and length of stay in health facilities can be significantly reduced (Edwards, Wyatt \& McKee, 2004, p. 4).

Global awareness about the role of facility management on improving outcomes of the overall organization such as higher quality and satisfaction levels and lower costs has been increasing in a growing competitive environment (Roper \& Borello, 2014; Han \& Hyun, 2015).

\subsection{Strategic Facility Management}

The approach to the concept of facility management has displayed a development from the limited coverage such as planning of maintenance, repair, and cleaning to the viewpoint based on the satisfaction of stakeholders now and in the future (Bernard \& Payant, 2007; Ginter, Duncan \& Swayne, 2013; Roper \& Borello, 2014). While it is becoming more difficult to predict the needs of business in the future, facility managers must consider strategic facility management (SFM) instead of the view point of traditional FM. SFM's intention should be adding more value to the medical core activities for their customers (stake- holders). The primary goal of this intention should be placed on decreasing the inconsistent outcomes of core business activities although it also focuses on lowering costs (Hofer \& Stampfli, 2012; Roper \& Borello, 2014, pp. 8-9).

On the other hand, the new perspective on the facility management should be at macro level, and related to the expectations of stakeholders instead of at the level of organization. This kind of viewpoint means that the managers find out new sources of value creating via SFM. At the end, not only medical business survives, but also this allows the increase of social welfare (Roper \& Borello, 2014).

\subsection{Strategic Management of Medical Facilities}

The potential contributions of the strategic approach of FM applications to the core business activities have recently started to be investigated. Reimbursement systems of case-mix, which is a kind of payment of health benefits in the form of a predetermined healthcare package bill, force the medical businesses to find out the new ways of reducing their costs without compromising quality. "Facility management expenditure takes second place after staff expenses" (Roper \& Borello, 2014, p. 2). Facility management that is still neglected may be a substantial tool that the managers of medical tourism can strategically use.

Medical industry continues to pursue its transformation in a highly dynamic environment under the pressure of internal and external environmental factors. Almost everything in medical sector displays a rapid and complex change that generally occurs at irregular periods. Medical organizations in such a fast changing environment require managers to cope with change and to able to manage it. Managers should analyze the change in the environment of their organizations, understand this unstable change, determine the right strategies with the analyze results and their leadership capabilities, and manage the momentum (Ginter, Duncan \& Swayne, 2013).

Medical businesses must follow the continuously improving innovations in the field, update the infrastructural and educational investments to meet the changing requirements, whilst the problem of cost in terms of competition is still in front of the managers. In the mean time they also have to assure the expected quality and newer methods of medical operations. 


\subsection{Performance Factors of Strategic Facility Management}

Before the determination and implementation of FM strategies, manager needs to find out the performance fields of SFM in order to connect them with the expectancies of stakeholders (Amaratunga, Baldry \& Sarshar, 2000; Amaratunga, Haigh, Sarshar \& Baldry, 2002; Tarcan, 2005). In literature, some drivers that the facility managers should take into account are defined as main features encouraging successful implementation of medical FM: "Traditional indicators of facility performance are the primarily financially, functionally and physically based ones" (Tarcan 2005, 939). Matthew Tucker evaluates the need of new FM indicators beyond the financial/quantitative based ones (Roper \& Borello, 2014, pp. 123-138). According to the Gallagher (1998) there are six main fields as strategic planning, patient care, FM, market testing, benchmarking and internal customer development. Kaplan and Norton (1996) suggest four key constructs of The Balance Scorecard - strategic performance measurement system as financial, customer, internal business process and learning, and growth.

On the other hand Amaratunga et al. (2002) define these features as "service requirements management, service planning, service performance monitoring, supplier and contractor management, health and safety processes, risk management, and service coordination.

The results of Tarcan's two studies $(2005 ; 2008)$ in the areas of $\mathrm{FM}$ of health care and sports indicate almost the same five constructs as the operational FM (OFM), financial, services (internal customers), external customers, and technology constructs (see Figure 1).
OFM construct covers metrics like "heating, lighting, energy efficiency, maintainability, durability, layout, ergonomics, image, ambience, communications, health and safety and flexibility metrics", etc. (Tarcan, 2008 , p. 625). Financial construct includes indicators such as the occupancy cost to $\mathrm{m}^{2}$, lease cost, vacant space as percentage of total space, $\mathrm{m}^{2}$ per person, facility utilizing, sponsorship, etc. (Tarcan, 2005; Tarcan, 2008). Services construct contains dimensions such as "facilities accessibility, regulations, environmental convenience, safety, location, disability access, equity, design and fit-out, building and satisfaction" (Tarcan, 2008, p. 627). External Customers Construct covers the external customer satisfaction related to the facilities (Tarcan, 2008). Technology construct includes criteria such as "technological sufficiency of facilities and technological education related to the facilities" and technology acceptance (Tarcan, 2008, p. 627; Varol \& Tarcan, 2009). It can be said that the constructs and components of Tarcan's two models (Figure 1 and 2) are similar to those in the literature and these models can be generalized with the help of new studies $(2005 ; 2008)$.

\section{CONCLUSIONS}

Medical Tourism being one of the most growing sectors in almost all of the developed and developing countries can be classified in the field of niche tourism. It ranges from the health care services involving a cure such as organ transplant, cardiac surgery, eye surgery, hip replacement, cosmetic dentistry and fertility treatments to the wellness services such as spa and detox involving no specific health trouble to pleasure and amusement services.

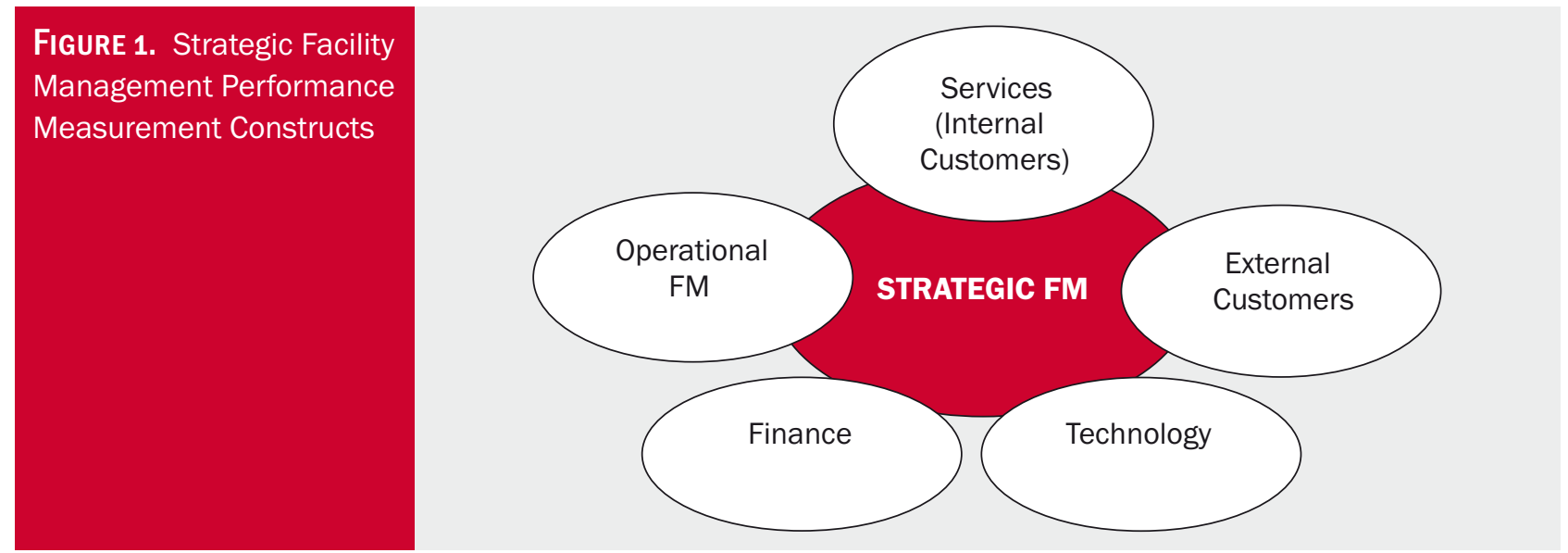

SouRcES: Tarcan, 2005, p. 942; Tarcan, 2008, p. 626 

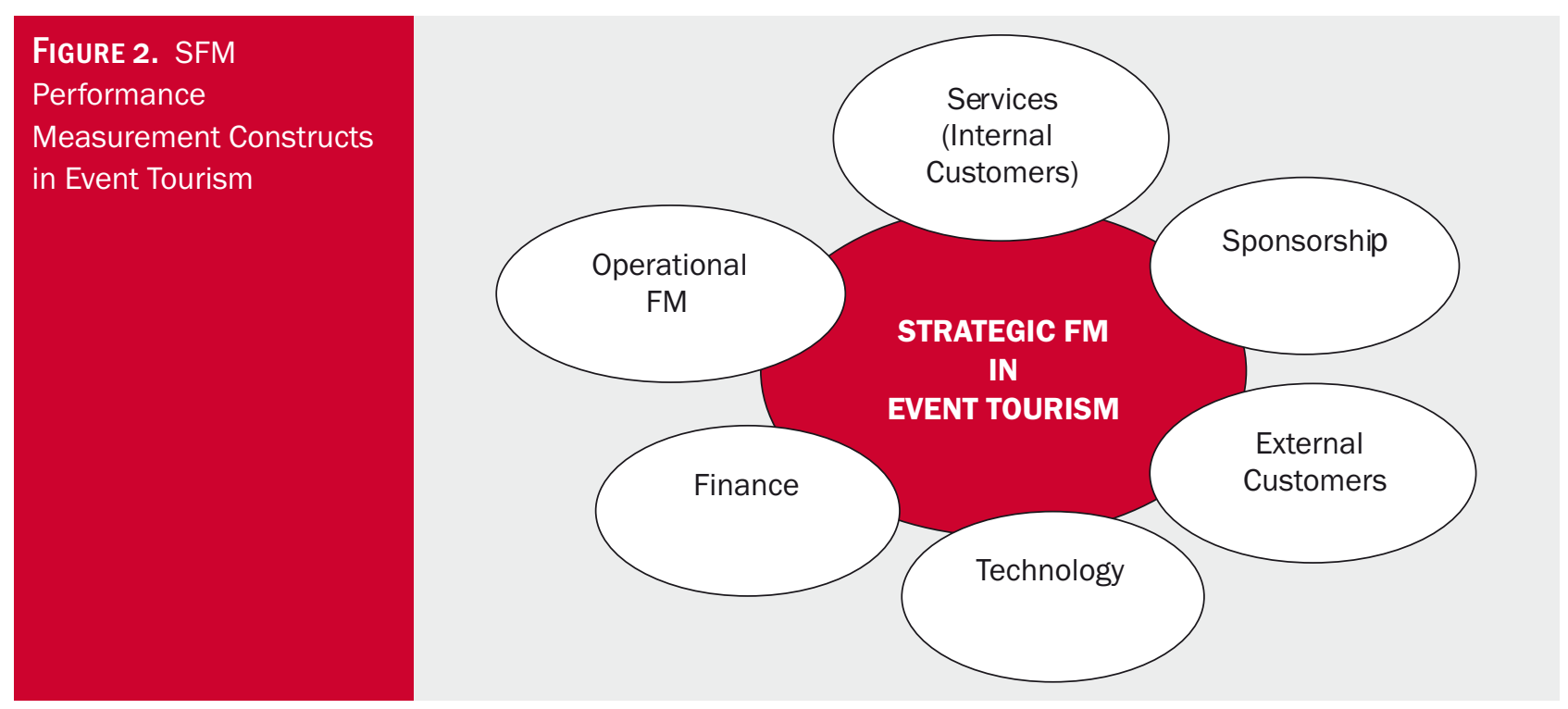

SOURCE: Tarcan, 2008, p. 626

Medical tourism might be one of the ways of solution for the lack of source on funding the health care expenditures. Medical tourism has also a role in creating of value for stakeholders as shareholders, internal customers, healthcare insurance systems, all of the sectors, etc.

Cost and quality of medical services are among the main reasons for the choice of medical tourism destination by medical tourists. Managers in this field can uncover some new ways of reducing costs and implement them while improving quality, without compromising on quality. Most of facilities, even the newer ones, create inconvenience conditions negatively affecting the outputs of core services. If they are properly managed, facilities may be an alternative source field that managers can use in order to be able to create value of cost and quality for their customers (stakeholders). Strategically managed medical facili- ties can ensure that businesses can be ready to resolve timely problems that may arise in the future in a relatively more dynamic environment than the other sectors.

Before the determination and implementation of FM strategies, manager needs to find out the performance fields of SFM in order to connect them with the expectancies of stakeholders. There is a need of newer indicators for SFM beyond the financial/quantitative based ones; SFM should continuously improve and use the performance related different tools of strategy choice such as the operational FM (OFM), financial, services (internal customers), external customers, and technology constructs. These constructs and their components will be changed according to the new studies to be done, and the fields of the medical tourism.

\section{References:}

1. Amaratunga, D., Baldry, D., Sarshar, M. (2000), "Assessment of facilities management performance what next?". Facilities, Vol. 18, No. 1/2, pp. 66-75.

2. Amaratunga, D., Haigh, R., Sarshar, M., Baldry, D. (2002) "Assessment of Facilities Management Process Capability: A NHS Facilities Case Study". International Journal of Health Care Quality Assurance, Vol. 15, No. 6, pp. 277-288.
3. Beladi H, Chao C, Ee M., Hollas D. (2015) "Medical Tourism And Health Worker Migration In Developing Countries". Economic Modelling [serial online]. Vol. 46, pp. 391-396.

4. Bernard, B., Payant, P. (2007) Facility Manager's Maintenance Handbook. (Second Edition). Mexico: McGraw Hill Professional. 
5. Connell, J. (2011) Medical Tourism, Wallingford, Oxon, GBR: CABI Publishing. ProQuest ebrary. Web. 6 May 2015.

6. Emslie, S., Knox, K., Pickstone, M. (2003). Improving Patient Safety: Insights from American, Australian and British Healthcare, Welwyn Garden City: ECRI.

7. Enderwick, P., Nagar, S. (2011) The Competitive Challenge Of Emerging Markets: The Case Of Medical Tourism, International Journal of Emerging Markets, Vol. 6, No. 4, pp. 329-350.

8. Gallagher, M. (1998), "Evolution Of Facilities Management In The Health Care Sector". Construction Papers, Vol. 86, No. 1-8.

9. Ginter, P.M., Duncan, W.J., Swayne, L. E. (2013) Strategic Management of Health Care Organizations (7th Edition), Somerset, NJ, USA: John Wiley \& Sons. ProQuest ebrary. Web. 7 May 2015.

10. Han H, Hyun S. (2015) "Customer Retention In The Medical Tourism Industry: Impact Of Quality, Satisfaction, Trust and Price Reasonableness". Tourism Management, Vol. 46, pp. 20-29.

11. Hofer, S., Stampfli, H. (2012) The perceived value of Facility Management in Swiss hospitals. Institute of Facility Management Working Paper, IFM - Institute of Facility Management Departement Life Sciences and Facility Management. http://ifm.zhaw.ch/ fileadmin/user_upload/life_sciences/_Institute_und_ Zentren/ifm/Dateien/Publikationen/05_Working Paper_Value_Hofer_Stampfli.pdf (11.12.2014)

12. International Facility Management Association (IFMA), What is FM?, http://www.ifma.org/knowbase/browse/what-is-fm- 03.03.2015

13. Kaplan, R.S., Norton, D.P. (1996) "Using The Balanced Scorecard As A Strategic Management System". Harvard Business Review, Vol. 74, No. 1, pp. 75-85.

14. Kshetri, N (2011). “The Healthcare Off-Shoring Industry In Developing Economies Institutional And Economic Foundations: An Indian Case". International Journal of Health Care Quality Assurance, Vol. 24, No. 6, pp. 453-470.

15. Mahbob, N.S., Kamaruzzaman, S.N., SallehN., Sulaiman,R. (2001) "A Correlation Studies of Indoor Environmental Quality(IEQ) Towards Productive Workplace". 2nd International Conference on Environmental Science and Technology: V2/434-V2438, Singapore: IACSIT Press. http://www. ipcbee.com/vol6/no2/96-F30033.pdf (1.03.2015)

16. Nicklin, W. (2012, updated) The Value and Impact of Health Care Accreditation: A Literature Review, Canada: Accreditation Canada.

17. Packer C., Labonté, R., Spitzer, D. (2007) Globalization and Health Worker Crisis, Globalization and Health Knowledge Network: Research Papers http://www.who.int/social_determinants/resources/ gkn_packer_al.pdf (05.03.2015)
18. Rechel, B., Wright, S., Edwards, N. (2009) Investing in Hospitals of the Future. Albany, NY, USA: WHO Regional Office for Europe. ProQuest ebrary. Web. (24.02.2015)

19. Roper, O. K., Borello, L.J. (2014) Innovation in the Built Environment: International Facility Management. John Wiley \& Sons, Incorporated. ProQuest ebrary. Web (06.02.2015).

20. Shiem, D., Then, S. (1999), "An Integrated Resource Management View Of Facilities Management”. Facilities, Vol. 12, No.13, pp. 462-469.

21. Sultana, S., Haque, A., Momen, A., Yasmin, F. (2014) "Factors Affecting the Attractiveness of Medical Tourism Destination: An Empirical Study on IndiaReview Article”. Iranian Journal of Public Health, Vol. 43, No. 7, pp. 867-876.

22. Tarcan, E. (1998) Facility Maintenance Management (Printed In Turkish - Bina ve Tesislerde Bakim Yonetimi). Istanbul, Turkey: Istanbul University, Basimevi Mudurlugu.

23. Tarcan, E. (2001) Quality In Service Management and Measurement of Customer Satisfaction (Printed In Turkish - Hizmet Yonetiminde Kalite ve Musteri Tatmini Olcumu). Istanbul, Turkey: Istanbul University, Cantay Kitap Evi.

24. Tarcan, E. (2005) Strategic facilities management and an exploratory study. International Strategic Management Conference: Strategic Management from National and Global Perspectives: 937-945, Canakkale, Turkey: Canakkale Onsekiz Mart University.

25. Tarcan, E. (2008) Strategic facilities management in event tourism and an exploratory study. International Tourism Conference: Cultural and Event TourismIssues \& Debates: 615-633, Alanya, Turkey: Akdeniz University.

26. Tarcan, E., Varol, E.S., Ates, M. (2004) “A Qualitative Study of Facilities and Their Environmental Performance". Management of Environmental Quality: An International Journal, Vol. 15, No.2, pp. 154-173.

27. The Joint Commission (2015) Survey Activity Guide For Health Care Organizations. http://www. jointcommission.org/assets/1/6/Organization_SAG. pdf (01.04.2015)

28. The World bank (2013) World Health Organization Global Health Expenditure Database, http:// data.worldbank.org/indicator/SH.XPD.TOTL.ZS (05.05.2015)

29. WHO Regional Office for the Western Pacific (1998) District Health Facilities: Guidelines for Development and Operations, http://www.who.int/management/ facility/hospital/en/

30. Varol, E.S., Tarcan, E. (2009) "An Emprical Study On The User Acceptance Of Hotel Information Systems". An International Interdisciplinary Journal TOURISM, 58 (2): 115-133. 


\section{Apstrakt:}

\section{Vrednovanje efekata strategijskog menadžmenta ustanova na izbor zdravstveno turističke destinacije}

Ertugrul Tarcan, Metin Ates, Ergin Sait Varol

Ova studija je bazirana na pregledu literature i usmerena na procenu i naglašavanje efekata strategijskog menadžmenta ustanova na izbor zdravstveno turističkog menadžmenta. Zdravstveni turizam, koji podrazumeva sirok spektar raznih usluga od usluga koje podrazumevaju lečenje i korišćenje leka do velnes usluga koje ne uključuju neki zdravstveni problem već zadovoljstvo i zabavu, jeste jedan od najbrže rastućih sektora na svetu. Troškovi i kvalitet zdravstvenih usluga su među vodećim razlozima za izbor destinacije. Strategijski menadžment ustanova je pozitivno koreliran sa nivoom kvaliteta, troškova i satisfakcijom korisnika. Zbog toga bi turistički menadžeri i menadžeri destinacija trebalo da uzimaju u obzir potencijalne prednosti kreiranja vrednosti putem strategijskog menadžmenta ustanova kako bi turisti birali tu destinaciju.

Ključne reči: strategijski menadžment ustanove, zdravstveni turizam, izbor destinacije.

Kontakt / Contact:

Ertugrul Tarcan

Istanbul University, Department of Business Administration, Maritime sciences and Marine Business Institute, Turkey, e-mail: ertugrultarcan@hotmail.com

Metin Ates

Marmara University, Department of Hospital Management, Health Sciences Faculty, Turkey, e-mail: atesmetin1@yahoo.com

Ergin Sait Varol Istanbul University, Vocational School of Technical Sciences, Turkey, e-mail: varol@istanbul.edu.tr 